\title{
Some Recommendations towards Reducing Electricity Consumption in the South African Manufacturing Sector
}

\author{
JN Blignaut and $\mathbf{T}$ de Wet $^{1}$
}

Department of Economics, University of Pretoria

\section{ABSTRACT}

This paper investigates the means of reducing electricity consumption in the South African manufacturing sector. It concludes that neither the price of electricity, nor taxes, subsidies or legislation are likely to bring about the required change. A change in the production structure using relatively more labour and less capital is also unlikely in the immediate future, given the socioeconomic and legislative milieu currently prevailing in South Africa. The only feasible solution that seems likely is a change in technology, which includes the more efficient use of electricity. Given the possible international agreement regarding global climate change commitments and procedures, clean development mechanisms may therefore yet provide the answer.

JEL N 67

\section{INTRODUCTION AND PROBLEM STATEMENT}

Few would deny the importance of electricity or of a strong manufacturing sector in the economic development of a country. Within the context of global climate change and the negative environmental impact of the externalities associated with the generation of electricity, it is increasingly important to reduce the levels of electricity consumption without jeopardising the manufacturing base of the economy. It is therefore valid to ask what measures are necessary to reduce electricity consumption by the manufacturing sector.

In an attempt to answer the question, this paper starts by giving an overview of the consumption and production of electricity in South Africa, followed by a discussion of the research method used. Then the price elasticity of electricity demand is investigated. This, in turn, is followed by a discussion of the production structure of manufacturing, and the correlation between the use of capital and electricity. Finally, some concluding remarks are made. 


\section{CONSUMPTION AND PRODUCTION OF ELECTRICITY IN SOUTH AFRICA: AN OVERVIEW}

\subsection{Demand for Electricity}

Electricity is an essential input in any economy, particularly in a developing country, since without it little development is possible. It is therefore not surprising that the Reconstruction and Development Programme (RDP) stresses the importance of an increased provision of electricity in the following terms (ANC, 1994: 108): "The benefits of cheap electricity presently enjoyed by large corporations must be extended to all parts of the economy."

From this statement it follows that, from the outset, it was the aim of the ANC to continue to supply cheap electricity and to extend its consumption to as many people as possible. There is no question that this objective has enjoyed high priority and that considerable progress has been made in pursuit of it (NER Annual Report, 1998). This is supported by the fact that the average annual growth in electricity consumption is highest in the residential sector, namely 4 per cent (see Table 1).

From Table 1 it is also clear that manufacturing is the largest single consumer of electricity (comprising approximately 41 per cent of total demand). Furthermore, the rate at which electricity consumption is growing in this sector is faster than the national average of 1,8 per cent a year over the period 1989 1995 , namely 2,1 per cent. Since manufacturing is such a major consumer of electricity, this paper focuses on this sector only.

Table 1 Electricity consumption in South Africa: 1989-1995 (GWh)

\begin{tabular}{|l|r|r|r|r|r|r|r|}
\hline Consumer & $\mathbf{1 9 8 9}$ & $\begin{array}{r}\% \text { of } \\
\text { total }\end{array}$ & $\mathbf{1 9 9 2}$ & $\begin{array}{r}\text { \% of } \\
\text { total }\end{array}$ & $\mathbf{1 9 9 5}$ & $\begin{array}{r}\text { \% of } \\
\text { total }\end{array}$ & $\begin{array}{c}\text { Annual } \\
\text { growth } \\
\text { rate }\end{array}$ \\
\hline Mining & 34963 & 24.94 & 33359 & 23.49 & 33612 & 21.59 & $-0.7 \%$ \\
\hline Transnet Ltd. & 4915 & 3.51 & 4347 & 3.06 & 4036 & 2.59 & $-3.2 \%$ \\
\hline Domestic use & 21125 & 15.07 & 23834 & 16.78 & 26663 & 17.13 & $4.0 \%$ \\
\hline Manufacturing & 56163 & 40.07 & 54474 & 38.35 & 63801 & 40.99 & $2.1 \%$ \\
\hline $\begin{array}{l}\text { Commerce, con- } \\
\text { struction, and other } \\
\text { business }\end{array}$ & 14282 & 10.19 & 15715 & 11.06 & 17513 & 11.25 & $3.5 \%$ \\
\hline Other purpose & 8721 & 6.22 & 10301 & 7.25 & 10034 & 6.45 & $2.4 \%$ \\
\hline Total & 140169 & 100 & 142031 & 100 & 155661 & 100 & $1.8 \%$ \\
\hline
\end{tabular}

Source: $\quad$ Stats SA, Census of Electricity, Gas and Steam 1995. 


\subsection{Supply of Electricity}

ESKOM is by far the largest single producer of electricity in South Africa, and is currently the fifth largest electricity utility in the world in terms of both sales and capacity (ESKOM Annual Report, 1999). Not only is it such a large producer of electricity, its share in domestic production has also increased considerably since 1960. As is indicated in Table 2, ESKOM produced 62.3 per cent of the total electricity in 1960 , and 98.3 per cent in 1999 , mainly through its coal-based fire stations. In 1960, all of the electricity produced was coal-based, but due to other technologies such as nuclear power, coal's contribution has declined slightly to approximately 93 per cent in 1999. Consequently, ESKOM is the largest single consumer of coal in South Africa, absorbing approximately 40 per cent of the total coal production in 1999. Its consumption of coal increased more than seven fold over the period under consideration from 12.5 million tonne to 88.5 million tonne. For comparative purposes, this consumption of coal should be seen in the light of the fact that total coal exports comprised 29.5 per cent of the market in the same year. (South Africa is the world's second largest exporter of coal with Australia being first and America third).

Table 2 Selected energy and electricity statistics in South Africa: 19601999

\begin{tabular}{|c|r|r|r|r|r|r|}
\hline & $\begin{array}{c}\text { Coal } \\
\text { production } \\
\text { (million } \\
\text { tonnes) }\end{array}$ & $\begin{array}{c}\text { Coal con- } \\
\text { sumption } \\
\text { for elect. } \\
\text { generation } \\
\text { (million } \\
\text { tonnes) }\end{array}$ & $\begin{array}{c}\text { Coal con- } \\
\text { sumption by } \\
\text { ESKOM } \\
\text { (million } \\
\text { tonnes) }\end{array}$ & $\begin{array}{c}\text { Total } \\
\text { electricity } \\
\text { genersted } \\
\text { (GWh) }\end{array}$ & $\begin{array}{c}\text { ESKOM's } \\
\text { contribution } \\
\text { to local } \\
\text { electricity } \\
\text { supply } \\
\text { (GWh) }\end{array}$ & $\begin{array}{c}\text { Electricity } \\
\text { supply: coal } \\
\text { fired } \\
\text { ESKOM } \\
\text { pwr pint } \\
\text { (GWh) }\end{array}$ \\
\hline 1960 & 38.1 & 16.4 & 12.5 & 25840 & 16094 & 17306 \\
\hline 1965 & 47.6 & 22.1 & 16.7 & 34490 & 23143 & 24583 \\
\hline 1970 & 53.1 & 29.5 & 21.6 & 50791 & 34890 & 37321 \\
\hline 1975 & 69.1 & 39.1 & 34.2 & 74894 & 57869 & 60400 \\
\hline 1980 & 113.1 & 55.0 & 46.8 & 98951 & 87539 & 82342 \\
\hline 1985 & 172.0 & 67.4 & 59.5 & 141384 & 112305 & 113941 \\
\hline 1990 & 184.1 & 76.2 & 70.9 & 165516 & 144440 & 134744 \\
\hline 1992 & 176.1 & 78.0 & 75.9 & 166260 & 146392 & 136830 \\
\hline 1995 & 212.5 & 87.6 & 79.4 & 174571 & 161848 & 151730 \\
\hline 1997 & 224.5 & 93.6 & 90.2 & 190700 & 181372 & 170464 \\
\hline 1999 & 220.74 & 93.4 & 88.5 & 191734 & 177934 & 165665 \\
\hline
\end{tabular}

Sources: DME, South African Energy Statistics No. 2, 1995. DME, South Africa's Mineral Industry 1998/99, 1999. ESKOM, Annual Report, 
various issues. NER, Annual Reports, various issues. Stats SA, Census of Electricity, Gas and Steam 1995, 1995. Chamber of Mines, Mining Statistics in Brief 1999, 2000.

\subsection{Electricity Prices}

ESKOM has committed itself to be one of the producers of electricity at the lowest cost in the world (ESKOM Annual Report, 1999). ESKOM's tariffs are much lower than those of many developed nations with electricity utilities of comparable size, for example Japan, Germany, the United Kingdom and the United States (Van Horen, 1996: 8). According to Doppegieter (1999: 52) South Africa has the second cheapest electricity in the world, beaten only by New Zealand. In the national context, electricity prices have declined in real terms since ESKOM announced its price compact in 1991. In announcing and motivating the price compact, ESKOM was convinced that cheap electricity is essential for rapid economic growth (Van Horen, 1996: 9). In terms of this price compact, ESKOM undertook to decrease the real price of electricity substantially over the period 1992-2000. The achieved price reductions over the period 1970-1999, are shown in Table 3. From this table it emerges that the real price of electricity $(1995=100)$ for all economic sectors declined by 7.8 per cent, and that for the manufacturing sector by 21.1 per cent over the whole period. Since 1990, the price of electricity for all sectors declined by 29.5 per cent and that for manufacturing by 35.6 per cent.

Table 3 Real electricity prices in South Africa: $1970-1999(\mathrm{c} / \mathrm{kWh})$

\begin{tabular}{|r|r|r|r|r|r|r|r|r|r|r|}
\hline & \multicolumn{2}{|c|}{ Ave: all sectors } & \multicolumn{2}{|c|}{ Manufacturing } & & \multicolumn{2}{c|}{ Ave: all sectors } & \multicolumn{2}{c|}{ Manufacturing } \\
\hline & $\begin{array}{c}\text { Real } \\
\text { price }\end{array}$ & $\begin{array}{c}\% \\
\text { change }\end{array}$ & $\begin{array}{c}\text { Real } \\
\text { price }\end{array}$ & $\begin{array}{c}\% \\
\text { change }\end{array}$ & & $\begin{array}{c}\text { Real } \\
\text { price }\end{array}$ & $\begin{array}{c}\% \\
\text { change }\end{array}$ & $\begin{array}{c}\text { Real } \\
\text { price }\end{array}$ & $\begin{array}{c}\% \\
\text { change }\end{array}$ \\
\hline 1970 & 10.29 & & 10.20 & & 1985 & 14.31 & -1.24 & 14.32 & -1.45 \\
\hline 1971 & 10.04 & -2.43 & 9.97 & -2.25 & 1986 & 14.60 & 2.03 & 14.73 & 2.86 \\
\hline 1972 & 10.02 & -0.20 & 9.86 & -1.10 & 1987 & 14.51 & -0.62 & 13.80 & -6.31 \\
\hline 1973 & 9.70 & -3.19 & 9.55 & -3.14 & 1988 & 14.09 & -2.89 & 13.15 & -4.71 \\
\hline 1974 & 9.16 & -5.57 & 9.48 & -0.73 & 1989 & 13.46 & -4.47 & 12.63 & -3.95 \\
\hline 1975 & 9.42 & 2.84 & 9.74 & 2.74 & 1990 & 13.45 & -0.07 & 12.50 & -1.03 \\
\hline 1976 & 11.05 & 17.30 & 11.34 & 16.43 & 1991 & 12.54 & -6.77 & 11.52 & -7.84 \\
\hline 1977 & 14.71 & 33.12 & 14.99 & 32.19 & 1992 & 11.90 & -5.10 & 10.62 & -7.81 \\
\hline 1978 & 15.41 & 4.76 & 15.50 & 3.40 & 1993 & 12.01 & 0.92 & 9.88 & -6.97 \\
\hline 1979 & 14.46 & -6.16 & 14.41 & -7.03 & 1994 & 11.15 & -7.16 & 9.68 & -2.02 \\
\hline 1980 & 13.54 & -6.36 & 13.55 & -5.97 & 1995 & 11.15 & 0.00 & 10.40 & 7.44 \\
\hline
\end{tabular}


Table 3 continued

\begin{tabular}{|c|c|c|c|c|c|c|c|c|c|}
\hline & \multicolumn{1}{|c|}{ Ave: all sectors } & \multicolumn{2}{c|}{ Manufacturing } & & \multicolumn{2}{c|}{ Ave: all sectors } & \multicolumn{2}{c|}{ Manufacturing } \\
\hline & $\begin{array}{c}\text { Real } \\
\text { price }\end{array}$ & $\begin{array}{c}\% \\
\text { change }\end{array}$ & $\begin{array}{c}\text { Real } \\
\text { price }\end{array}$ & $\begin{array}{c}\% \\
\text { change }\end{array}$ & & $\begin{array}{c}\text { Real } \\
\text { price }\end{array}$ & $\begin{array}{c}\% \\
\text { change }\end{array}$ & $\begin{array}{c}\text { Real } \\
\text { price }\end{array}$ & $\begin{array}{c}\% \\
\text { change }\end{array}$ \\
\hline 1981 & 13.24 & -2.22 & 13.25 & -2.21 & 1996 & 10.53 & -5.56 & 9.41 & -9.52 \\
\hline 1982 & 14.19 & 7.18 & 14.30 & 7.92 & 1997 & 10.17 & -3.42 & 9.25 & -1.70 \\
\hline 1983 & 15.17 & 6.91 & 15.24 & 6.57 & 1998 & 9.86 & -3.05 & 8.84 & -4.43 \\
\hline 1984 & 14.49 & -4.48 & 14.53 & -4.66 & 1999 & 9.49 & -3.75 & 8.05 & -8.94 \\
\hline & & & & & & $\begin{array}{c}\text { Over } \\
\text { period }\end{array}$ & -7.77 & $\begin{array}{r}\text { Over } \\
\text { period }\end{array}$ & -21.08 \\
\hline
\end{tabular}

Source: $\quad$ DME, South African National Energy Prices, 2000: 70.

The low and declining price of electricity encouraged the consumption of electricity to grow at the average annual rate of 5.4 per cent from 1960 to 1999 . From 1990 to 1999 , the average annual growth rate of electricity consumption was 1.9 per cent, which is marginally higher than the increase in the real Gross Domestic Product of 1.6 per cent over the same period. However, according to Doppegieter (1998: 3-59) such figures are misleading. Electricity is consumed wastefully in South Africa and much electricity can be saved. The inefficient use of electricity is attributed to a number of reasons, amongst others the low coal and electricity prices and large coal reserves.

One of the major factors contributing to the low electricity price is the relative cheap coal that ESKOM buys. In 1998, ESKOM paid an average price of R41.31/tonne, compared to the R54.55/tonne Sasol paid, and the R156.36/tonne the metallurgic industries paid. These price differences can be attributed to different contract arrangements, entitlements and differences in the quality of coal (DME, 1999).

\subsection{The Social and Environmental Cost of Electricity Generation}

The increase in the consumption of both coal and electricity contributes not just to economic growth, but also to the increase in negative social and environmental externalities. From Table 4 is it clear that ESKOM is a dominant polluter of greenhouse gases in South Africa, contributing to more that 45 per cent of domestic emissions. These emissions are mainly derived from the coalbased plants of ESKOM. 
Table 4 Carbon dioxide, Sulphur dioxide and Nitrogen emissions in South Africa: 1990, 1994 and 1995

\begin{tabular}{|c|c|c|c|c|c|c|c|c|c|}
\hline & \multicolumn{3}{|c|}{$\mathrm{CO}_{2}$ (Million tonnes) } & \multicolumn{3}{|c|}{$\mathrm{SO}_{2}$ (Thousand tonnes) } & \multicolumn{3}{|c|}{$\begin{array}{c}\mathrm{NO}_{x} \text { (Thousand } \\
\text { tonnes) }\end{array}$} \\
\hline & $\begin{array}{c}\text { ES- } \\
\text { KOM }\end{array}$ & $\mathbf{S A}$ & $\begin{array}{l}\text { ESKOM } \\
\% \text { of SA }\end{array}$ & ESKOM & $\overline{\mathbf{S A}}$ & $\begin{array}{l}\text { ESKOM } \\
\% \text { of SA }\end{array}$ & $\begin{array}{c}\text { ES- } \\
\text { KOM }\end{array}$ & SA & $\begin{array}{l}\text { ESKOM } \\
\% \text { of SA }\end{array}$ \\
\hline 1990 & 132.75 & .386 & 45.2 & 1088.32 & 1760.0 & 61.8 & 913.8 & 2268 & 40.3 \\
\hline 1994 & 142.94 & 317.861 & 45.0 & 1166.80 & & & 961.2 & & \\
\hline 1995 & 146.95 & 305.805 & 48.1 & 1198.17 & & & & & \\
\hline 1997 & 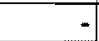 & 345.000 & - & - & 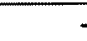 & - & - & - & \\
\hline
\end{tabular}

Sources: $\quad$ Doppegieter, 1998: 3-69 \& 3-80. Van der Merwe \& Scholes, 1999.

UNFCCC, 2000 .

Viewed from an international perspective, South Africa was the $15^{\text {th }}$ highest emitter of carbon dioxide in 1995 and 1997 in absolute terms (Doppegieter, 1998: 3-69 \& UNFCCC, 2000). South Africa was hence the $10^{\text {th }}$ highest nonAnnex 1 ( $c f$. developing country) polluter of carbon dioxide per capita in both 1995 and 1997 , or $28^{\text {th }}$ overall (including the developed economies) (Doppegieter, 1998: 3-69 \& UNFCCC, 2000). These rankings do not reflect the country's economic strength and are clearly disproportionate.

Chronic exposure to emissions of this magnitude has serious mortality and morbidity implications, such as chronic bronchitis and other respiratory diseases. Acid deposition in water bodies also severely impacts on the quality of surface and even ground water. This health hazard is further magnified by the fact that there is sufficient evidence to believe that global climate change is mainly due to anthropocentric (economic) activities (Houghton et al., 1996).

In the light of these environmental and social costs due to the extemality associated with coal-based electricity generation (see also Van Horen, 1996 \& 1997), there is a need to reduce the generation of electricity from this source. This can be achieved in one of two ways, or a combination of both. ESKOM can change its production technology, that is divert from coal to alternative energy sources, or there should be a decline in the consumption of coal-based electricity. A possible change in the production technology of ESKOM and its associated cost will, however, not be discussed here. The remainder of this paper will focus on the demand for electricity by the largest single consumer of electricity, the manufacturing sector, and an appropriate policy required to bring about a reduction in the consumption of electricity. 


\section{METHOD AND DATA}

In the attempt to find an appropriate policy to reduce the consumption of electricity in the manufacturing sector, this study investigates the effect of a change in the price of electricity on the consumption of energy by calculating the price elasticity of electricity demand. Because of data limitations, a static approach had to be used and elasticity was calculated on the ceteris paribus assumption, that all other factors that might influence electricity demand remain constant. This exercise produced some surprising results, which caused the authors to investigate the production structure in manufacturing by means of a Cobb-Douglas production function, estimated for each year in the sample period. These estimates indicate that the production structure in South African manufacturing has changed rather drastically and that this change has socioeconomic as well as environmental consequences. Based on these results, the effect of the change in production structure on electricity consumption in South Africa was tested and some policy proposals for the reduction of electricity consumption in manufacturing were made.

The data used in the empirical tests was obtained from Statistics South Africa's census of manufacturing and the Department of Mineral and Energy Affairs' yearbooks. The sample years included in the study are 1972, 1976, 1979, 1982, 1985, 1988, 1991, 1993 and 1996. The manufacturing sector has been disaggregated into 27 subsectors. This implies a cross-sectional data set for nine years across 27 subsectors.

The data for estimating the price elasticities are the price of electricity measured in R/MWh and the total consumption of electricity measured in MWh for the 27 subsectors. The data used for estimating production functions for the manufacturing industry, and in calculating the effect of structural change in production on electricity use, are net production (i.e. tumover less consumption of fixed capital), the value of fixed capital stock and the cost of electricity. These aggregates are expressed in constant 1995 prices. Each of these three variables is then expressed as a ratio of the number of labourers employed. All variables are published in nominal terms only, and the GDP deflator was used to deflate fixed capital stock whilst the CPI was used to deflate the other variables.

\section{4 \\ PRICE ELASTICITY OF ELECTRICITY DEMAND IN THE SOUTH AFRICAN MANUFACTURING SECTOR}

There exists, at least theoretically, a negative correlation between the volume consumed of any commodity and its price, ceteris paribus. One of the easiest, and generally accepted, methods to measure the quantity to which electricity 
consumption will change with a change in price is, by calculating the price elasticity of electricity demand ${ }^{2}$. The calculated price elasticity of demand for electricity is reported in Table 5:

Table 5 Price elasticity of demand for electricity in 27 manufacturing subsectors in the South African economy: 1976-1996

\begin{tabular}{|c|c|c|c|c|c|c|c|c|c|}
\hline & 1976 & 1979 & 1982 & 1985 & 1988 & 1991 & 1993 & 1996 & $\begin{array}{c}\text { Ave. } \\
\text { over } \\
\text { period }\end{array}$ \\
\hline Food & 0.743 & 0.074 & 0.659 & 0.281 & 0.300 & -2.179 & 4.406 & -0.674 & 0.156 \\
\hline Beverage industries & 1.203 & -0.231 & 0.385 & -0.031 & 0.654 & -2.877 & 2.763 & -0.503 & 0.105 \\
\hline Tabacco products & 1.007 & 0.405 & 0.187 & 0.243 & 0.882 & -0.406 & 1.220 & 1.367 & .720 \\
\hline Textiles & 0.540 & -0.052 & -0.013 & -0.023 & 4.486 & 5.043 & -1.550 & 0.709 & 0.047 \\
\hline $\begin{array}{l}\text { Wearing apparel, } \\
\text { except footware }\end{array}$ & 0.707 & 0.019 & 0.384 & -0.040 & 0.673 & -1.816 & 8.752 & -0.143 & 0.451 \\
\hline leather & 0.712 & -0.318 & 0.181 & -0.142 & 0.860 & -2.336 & 3.305 & 1.082 & .172 \\
\hline Footwe & 536 & -0.160 & 345 & 0.040 & 0.615 & 0.775 & 2.584 & -0.669 & .232 \\
\hline $\begin{array}{l}\text { Wood and wood and } \\
\text { cork products, except } \\
\text { furniture }\end{array}$ & 0.745 & -0.255 & 0.884 & -0.019 & 0.806 & -2.194 & 5.467 & 0.287 & 389 \\
\hline $\begin{array}{l}\text { Furniture and fixtures, } \\
\text { except primarily of } \\
\text { metal }\end{array}$ & 0.615 & -0.056 & 0.986 & 0.260 & 1.080 & -2.367 & 9.345 & -2.130 & 0.316 \\
\hline nd paper & 0.620 & 0.182 & 522 & 1.524 & 0.319 & 157 & -1.490 & 1.313 & 255 \\
\hline lishing & 1.2 & 0.641 & 495 & 0.295 & 0.778 & 217 & 5.403 & -0.643 & 0.299 \\
\hline Indust & 1.60 & 0.512 & 439 & 0.222 & 1.085 & 1.018 & 6.227 & 0.715 & 0.831 \\
\hline Other chemical & -0.248 & 0.170 & 0.251 & 1.883 & 0.658 & -1.180 & -17.946 & 1.692 & 0.250 \\
\hline Rubl & 2.498 & -0.208 & 0.090 & -0.313 & 0.146 & .040 & 4.186 & 0.330 & 0.760 \\
\hline $\begin{array}{l}\text { Plastic products, not } \\
\text { elsewhere classified }\end{array}$ & 1.122 & 0.202 & 1.020 & 0.342 & 0.661 & -1.236 & 3.811 & 1.557 & 0.793 \\
\hline $\begin{array}{l}\text { Pottery, china and } \\
\text { earthenware }\end{array}$ & 0.552 & -0.150 & 781 & 0.058 & -0.414 & .173 & 3.746 & 1.046 & 0.302 \\
\hline $\begin{array}{l}\text { Glass and glass } \\
\text { products }\end{array}$ & 0.564 & -0.504 & 0.527 & -0.099 & 0.716 & 715 & 1.546 & 0.274 & -0.099 \\
\hline $\begin{array}{l}\text { Other non-metallic } \\
\text { products }\end{array}$ & 0.417 & -0.250 & 485 & 0.722 & -1.841 & .635 & -1.077 & 0.494 & -0.306 \\
\hline $\begin{array}{l}\text { Iron and steel basic } \\
\text { industries }\end{array}$ & 0.597 & 0.666 & 0.119 & 0.252 & 1.224 & -1.974 & 3.460 & 0.805 & 0.571 \\
\hline $\begin{array}{l}\text { Non-ferrous metal } \\
\text { basic industries }\end{array}$ & 0.580 & 0.402 & 0.137 & 0.567 & 1.085 & -2.509 & 6.172 & 2.921 & 0.708 \\
\hline
\end{tabular}


Table 5 continued

\begin{tabular}{|c|c|c|c|c|c|c|c|c|c|}
\hline & 1976 & 1979 & 1982 & 1985 & 1988 & 1991 & 1993 & 1996 & $\begin{array}{c}\text { Ave. } \\
\text { over } \\
\text { period }\end{array}$ \\
\hline $\begin{array}{l}\text { Fabricated metal } \\
\text { products, except } \\
\text { machinery and } \\
\text { equipment }\end{array}$ & 0.825 & 0.020 & 0.790 & 0.507 & 0.352 & -1.298 & 2.409 & 0.103 & 0.292 \\
\hline $\begin{array}{l}\text { Machinery, except } \\
\text { electrical machinery }\end{array}$ & 0.678 & 0.109 & 0.846 & -0.286 & 0.203 & -1.882 & 3.242 & -1.994 & 0.030 \\
\hline $\begin{array}{l}\text { Electrical machinery, } \\
\text { apparatus, appliances } \\
\text { and supplies }\end{array}$ & 1.116 & 242 & 0.262 & -0.161 & 0.74 & 1.653 & 6.329 & -0.607 & 0.485 \\
\hline $\begin{array}{l}\text { Motor vehicles, parts } \\
\text { and accessories }\end{array}$ & 0.547 & 0.054 & 0.852 & -0.278 & 0.450 & -1.567 & 6.720 & 0.167 & 0.428 \\
\hline $\begin{array}{l}\text { Transport equipment, } \\
\text { except motor vehicles, } \\
\text { parts and accessories } \\
\text { Professional and } \\
\text { scientific, measuring } \\
\text { and controlling } \\
\text { equipment, } \\
\text { photographic and } \\
\text { optical goods, }\end{array}$ & 0.564 & 0.106 & -0.220 & -0.652 & 0.171 & -2.500 & -7.425 & -2.825 & 0.209 \\
\hline $\begin{array}{l}\text { Other manufacturing } \\
\text { industries }\end{array}$ & 0.502 & 0.11 & 0.869 & 0.236 & 0.258 & -1.182 & 2.243 & 3.042 & 0.517 \\
\hline
\end{tabular}

Source: Own analysis.

Two things are evident from Table 5. Firstly, in most subsectors an increase in the price of electricity has not resulted in a decrease in the use of (i.e. quantity demanded of) electricity. One might at least have expected that in the majority of cases price elasticity of demand would have a negative sign, but this is not the case. Secondly, the price elasticities are small and lie between 1 and -1 , indicating that electricity consumption is price inelastic.

One may therefore conclude that the manufacturing sector is not sensitive to the price of electricity in its decision-making. This outcome is in line with earlier results (Van Horen, 1997: 66).

As mentioned above, electricity is cheap in South Africa and its price declining. This has resulted in the cost of electricity as a percentage of total cost for almost all subsectors and in all the years being less than 10 per cent, with an average of 4.5 per cent over all the years and subsectors. This can be seen in Table 6 . These results indicate that there should be other, non-price, factors causing electricity consumption to change in the South African manufacturing sector. 
These results reiterate that the price of electricity is a very weak instrument to bring about a change in electricity consumption in South African manufacturing. The following section examines the change in production technology in the South African manufacturing sector since 1972, to determine what does in fact cause electricity consumption to change.

Table 6 Electricity cost as percentage of total cost in $\mathbf{2 7}$ manufacturing subsectors in South Africa: 1972-1996

\begin{tabular}{|c|c|c|c|c|c|c|c|c|c|c|}
\hline $\begin{array}{l}\text { Industry: } \\
\text { Description }\end{array}$ & 1972 & 1976 & 1979 & 1982 & 1985 & 1988 & 1991 & 1993 & 1996 & Ave. \\
\hline Food & 6.624 & 8.687 & 10.189 & 11.632 & 9.138 & 9.136 & 3.632 & 4.481 & 1.043 & 3.082 \\
\hline Beverage industries & 4.649 & 11.765 & 10.581 & 10.547 & 9.905 & 8.045 & 2.301 & 2.574 & 0.658 & 2.209 \\
\hline Tabacco products & 1.635 & 3.303 & 4.074 & 8.981 & 7.631 & 4.203 & 3.440 & 3.267 & 1.051 & 2.108 \\
\hline Textiles & 5.272 & 7.453 & 9.563 & 8.445 & 8.111 & 0.921 & 4.167 & 4.515 & 1.773 & 3.389 \\
\hline $\begin{array}{l}\text { Wearing apparel, } \\
\text { except footware }\end{array}$ & 1.190 & 1.724 & 2.448 & 2.217 & 2.062 & 2.884 & 1.185 & 1.794 & 0.631 & 1.195 \\
\hline $\begin{array}{l}\text { Leather and leather } \\
\text { products }\end{array}$ & 3.390 & 515 & 5.249 & 5.253 & 5.349 & 6.366 & 2.353 & 714 & 0.687 & 1.751 \\
\hline Footwear & 1.467 & 848 & 2.182 & 1.931 & 2.061 & 2.419 & 1.328 & 1.611 & 0.598 & 1.205 \\
\hline $\begin{array}{l}\text { Wood and wood and } \\
\text { cork products, except } \\
\text { furniture }\end{array}$ & 5.660 & 7.189 & 7.935 & 9.207 & 8.493 & 10.678 & 4.365 & 6.530 & 1.796 & 4.004 \\
\hline $\begin{array}{l}\text { Furniture and } \\
\text { fixtures, except } \\
\text { primarily of metal }\end{array}$ & 2.069 & 263 & 465 & 4.414 & 3.893 & 5.309 & 1.858 & 868 & 0.931 & .214 \\
\hline $\begin{array}{l}\text { Paper and paper } \\
\text { products }\end{array}$ & 9.254 & 9.196 & 19.376 & 11.675 & 15.361 & 16.988 & 6.451 & 5.579 & 1.916 & 4.985 \\
\hline $\begin{array}{l}\text { Printing, publishing } \\
\text { and allied industries }\end{array}$ & 1.326 & 2.527 & 2.440 & 2.427 & 2.369 & 3.090 & 1.260 & 1.750 & 0.607 & 1.312 \\
\hline Industrial & 8.968 & 14.685 & $19.05 \mathrm{I}$ & 18.620 & 16.282 & 33.086 & 14.148 & 11.038 & 3.941 & 7.806 \\
\hline $\begin{array}{l}\text { Other chemical } \\
\text { products }\end{array}$ & 6.575 & 5.539 & 7.129 & 7.146 & 7.636 & 9.871 & 5.215 & 1.947 & 0.827 & 3.482 \\
\hline Rubber products & 1.542 & 7.960 & 8.882 & 6.850 & 7.307 & 6.490 & 3.731 & 4.784 & 1.932 & 3.660 \\
\hline $\begin{array}{l}\text { Plastic products, not } \\
\text { elsewhere classified }\end{array}$ & 3.181 & 4.892 & 6.248 & 7.393 & 6.960 & 7.277 & 3.645 & 4.262 & 1.779 & 3.144 \\
\hline $\begin{array}{l}\text { Pottery, china and } \\
\text { earthenware }\end{array}$ & 10.531 & 14.093 & 8.643 & 16.216 & 16.882 & 13.876 & 7.493 & 10.498 & 2.844 & 6.282 \\
\hline $\begin{array}{l}\text { Glass and glass } \\
\text { products }\end{array}$ & 16.910 & 23.100 & 23.531 & 20.112 & 23.829 & 22.790 & 7.138 & 9.796 & 3.421 & 8.689 \\
\hline $\begin{array}{l}\text { Other non-metallic } \\
\text { products }\end{array}$ & 16.995 & 20.295 & 23.892 & 26.052 & 32.903 & 16.515 & 8.115 & 8.115 & 3.313 & 9.415 \\
\hline $\begin{array}{l}\text { Iron and steel basic } \\
\text { industries }\end{array}$ & 13.34 & 13.913 & 24.010 & 23.719 & 28.248 & 49.209 & 21.144 & 29.991 & 9.028 & 17.876 \\
\hline $\begin{array}{l}\text { Non-ferrous metal } \\
\text { basic industries }\end{array}$ & .672 & .471 & 41.959 & 44.116 & 40.261 & 60.832 & 19.289 & 34.814 & 11.176 & 19.404 \\
\hline
\end{tabular}


Table 6 continued

\begin{tabular}{|l|c|c|c|c|c|c|c|c|c|c|}
\hline $\begin{array}{c}\text { Industry: } \\
\text { Description }\end{array}$ & 1972 & 1976 & 1979 & 1982 & 1985 & 1988 & 1991 & 1993 & 1996 & Ave. \\
\hline $\begin{array}{l}\text { Fabricated metal } \\
\text { products, except } \\
\text { machinery and } \\
\text { equipment }\end{array}$ & 3.147 & 4.262 & 5.505 & 5.736 & 5.211 & 6.322 & 3.256 & 4.004 & 1.279 & 2.825 \\
\hline $\begin{array}{l}\text { Machinery, except } \\
\text { electrical machinery }\end{array}$ & 2.649 & 3.121 & 4.324 & 3.955 & 4.428 & 5.202 & 2.013 & 2.902 & 0.658 & 1.994 \\
\hline $\begin{array}{l}\text { Electrical machi- } \\
\text { nery, apparatus, } \\
\text { appliances and } \\
\text { supplies }\end{array}$ & 2.106 & 3.100 & 4.851 & 4.387 & 4.179 & 4.960 & 2.339 & 3.451 & 0.959 & 2.131 \\
\hline $\begin{array}{l}\text { Motor vehicles, parts } \\
\text { and accessories }\end{array}$ & 2.848 & 3.185 & 4.423 & 4.847 & 3.496 & 4.507 & 1.945 & 2.915 & 0.560 & 1.372 \\
\hline $\begin{array}{l}\text { Transport equip- } \\
\text { ment, except motor } \\
\text { vehicles, parts and } \\
\text { accessories }\end{array}$ & 1.825 & 2.423 & 3.413 & 4.270 & 3.789 & 3.007 & 1.406 & 1.136 & 1.450 & 1.993 \\
\hline $\begin{array}{l}\text { Professional and } \\
\text { scientific, measu- } \\
\text { ring and controlling } \\
\text { equipment, photo- } \\
\text { graphic and optical } \\
\text { goods }\end{array}$ & 2.992 & 3.351 & 3.998 & 2.515 & 3.330 & 3.363 & 1.563 & 1.741 & 0.372 & 1.229 \\
$\begin{array}{l}\text { Other manufacturing } \\
\text { industries }\end{array}$ & 2.092 & 2.818 & 3.093 & 4.125 & 3.808 & 4.386 & 1.758 & 2.326 & 0.889 & 1.567 \\
\hline
\end{tabular}

Source: Own analysis.

\section{PRODUCTION FUNCTIONS FOR THE SOUTH AFRICAN MANUFACTURING SECTOR}

To calculate the change in production technology in the South African manufacturing sector since 1972, Cobb-Douglas production functions have been estimated for each of the sample years over the 27 subsectors. The function estimated for each year is given by:

$$
Q_{i}=c L_{i}^{a} C_{i}^{\beta} \varepsilon_{i}
$$

with $Q_{i}=$ Production in subsector $\mathrm{i}$

$L_{i}=$ Number of labourers employed in subsector $i$

$\mathrm{C}_{\mathrm{i}}=$ Capital employed in subsector $\mathrm{i}$

$\varepsilon_{\mathrm{i}}=$ Error term

$\alpha=$ Elasticity of labour

$\beta=$ Elasticity of capital 
The results of this estimation are reported in Table 7.

Table 7 Results of estimation of Cobb-Douglas production functions for the South African manufacturing sector: 1972-1996

\begin{tabular}{|c|r|r|r|r|}
\hline Date & \multicolumn{1}{|c|}{$\alpha$} & \multicolumn{1}{c|}{$\beta$} & $\alpha+\beta$ & \multicolumn{1}{c|}{$\boldsymbol{C}$} \\
\hline 1972 & 0.669556 & 0.276535 & 0.946091 & 3.619703 \\
& $(7.813961)$ & $(4.155798)$ & & $(5.133022)$ \\
\hline 1976 & 0.562570 & 0.366546 & 0.929116 & 3.514579 \\
& $(7.189039)$ & $(6.210758)$ & & $(6.298416)$ \\
\hline 1979 & 0.515375 & 0.425608 & 0.940983 & 3.173307 \\
& $(7.179832)$ & $(7.818833)$ & & $(5.776759)$ \\
\hline 1982 & 0.562756 & 0.398406 & 0.961162 & 3.153122 \\
& $(9.790596)$ & $(9.570515)$ & & $(7.280743)$ \\
\hline 1985 & 0.500285 & 0.382278 & 0.882563 & 4.037432 \\
& $(6.153849)$ & $(7.093315)$ & & $(6.752536)$ \\
\hline 1988 & 0.458135 & 0.423226 & 0.881361 & 3.963550 \\
& $(6.727693)$ & $(9.085144)$ & & $(7.676274)$ \\
\hline 1991 & 0.415977 & 0.480410 & 0.896387 & 3.624855 \\
& $(5.576698)$ & $(9.034326)$ & & $(6.771560)$ \\
\hline 1993 & 0.492383 & 0.392499 & 0.884882 & 4.076646 \\
& $(6.696717)$ & $(7.811565)$ & & $(6.712788)$ \\
\hline 1996 & 0.462675 & 0.451166 & 0.913841 & 6.592393 \\
& $(4.804403)$ & $(6.854599)$ & & $(8.855874)$ \\
\hline
\end{tabular}

Source: Own analysis.

From Table 7 one may conclude that the South African manufacturing sector is producing at constant returns to scale. This is indicated by the sum of the two elasticities $(\alpha+\beta)$ which remained approximately 0.9 from 1972 to 1996 , and is not statistically significantly different from 1 .

The most interesting result that emerges from these estimations, however, is that the elasticity of labour decreased significantly from 1972 to 1996. In 1972 the elasticity of labour was 0.66 and it decreased by approximately 30 per cent to 0.46 in 1996. In contrast to this, the elasticity of capital increased by approximately 67 per cent from 0.27 in 1972 to 0.45 in 1996. This indicates that capital's share as input in the production process increased considerably while that of labour decreased. It also implies that labour has been substituted by capital. If the increase in the use of capital results in an increase in the use of electricity, the substitution of capital for labour has an effect on the natural environment through an increase in emissions. This relationship between capital 
as input in the manufacturing sector and the use of electricity in manufacturing will be investigated next.

\section{CAPITAL AND ELECTRICITY USE IN THE SOUTH AFRICAN MANUFACTURING SECTOR}

Firstly, the correlation coefficients between capital and electricity use from 1972 to 1996 , within each subsector, were calculated to test whether a relationship exists between the use of capital in the manufacturing sector and electricity. The results from this estimation are reported in Table 8.

Table 8 Correlation coefficients between capital input and energy input in 27 subsectors in the manufacturing sector of South Africa: 1972-1996

\begin{tabular}{|l|c|}
\hline Industry: Description & $\begin{array}{c}\text { Correlation coefficient } \\
\text { between capital input } \\
\text { and electricity input }\end{array}$ \\
\hline Food & -0.100 \\
\hline Beverage industries & -0.133 \\
\hline Tabacco products & -0.770 \\
\hline Textiles & 0.289 \\
\hline Wearing apparel, except footware & 0.629 \\
\hline Leather and leather products & -0.257 \\
\hline Footwear & -0.207 \\
\hline Wood and wood and cork products, except furniture & 0.030 \\
\hline Furniture and fixtures, except primarily of metal & 0.428 \\
\hline Paper and paper products & 0.688 \\
\hline Printing, publishing and allied industries & -0.007 \\
\hline Industrial chemicals & 0.833 \\
\hline Other chemical products & 0.707 \\
\hline Rubber products & 0.101 \\
\hline Plastic products, not elsewhere classified & 0.817 \\
\hline Pottery, china and earthenware & 0.230 \\
\hline Glass and glass products & 0.217 \\
\hline Other non-metallic products & 0.774 \\
\hline Iron and steel basic industries & -0.564 \\
\hline Non-ferrous metal basic industries & 0.774 \\
\hline $\begin{array}{l}\text { Fabricated metal products, except machinery } \\
\text { equipment }\end{array}$ & 0.761 \\
\hline
\end{tabular}


Table 8 continued

\begin{tabular}{|l|c|}
\hline Industry: Description & $\begin{array}{c}\text { Correlation coefficient } \\
\text { between capital input } \\
\text { and electricity input }\end{array}$ \\
\hline Machinery, except electrical machinery & 0.738 \\
\hline Electrical machinery, apparatus, appliances and supplies & 0.630 \\
\hline Motor vehicles, parts and accessories. & -0.031 \\
\hline $\begin{array}{l}\text { Transport equipment, except motor vehicles, parts and } \\
\text { accessories }\end{array}$ & 0.315 \\
\hline $\begin{array}{l}\text { Professional and scientific, measuring and controlling } \\
\text { equipment, photographic and optical goods }\end{array}$ & 0.580 \\
\hline Other manufacturing industries & - \\
\hline
\end{tabular}

Source: Own analysis.

These results indicate a positive correlation between capital and electricity input in 19 of the 27 subsectors. This positive correlation indicates that an increase in capital will result in an increase in electricity input and vice versa.

Using another form of analysis, the results from the correlation coefficient calculation are confirmed by cross-sectional ordinary least squares estimation of the simple function,

$$
E_{i}=a_{i}+\not K_{i}+\varepsilon
$$

with $E_{i}=$ Electricity input for subsector $\mathrm{i}$

$\mathrm{K}_{\mathrm{i}}=$ Capital input for subsector $\mathrm{i}$

घi $=$ Error term

$\alpha_{i}=$ Constant

This has been done for all the sample years. The estimated coefficients are reported in Table 9, and confirm that an increase in capital does indeed result in an increase in energy input for each of the sample years. In each cross-sectional estimation the coefficient on capital is highly significant as indicated by the tvalues. 
Table 9 Results from cross-sectional ordinary least squares estimation of capital on energy input

\begin{tabular}{|l|c|c|c|}
\hline & $\begin{array}{c}\text { Constant } \\
\text { (t-value in parenthesis) }\end{array}$ & $\begin{array}{c}\text { Coefficient (t-value } \\
\text { in parenthesis) }\end{array}$ & Adj. R $^{2}$ \\
\hline 1972 & 92168.75 & 0.587700 & 0.848850 \\
\hline & $(0.633830)$ & $(11.89110)$ & \\
1976 & 458800.3 & 0.407422 & 0.850220 \\
\hline & $(2.569611)$ & $(12.18968)$ & \\
1979 & -6209.79 & 0.662099 & 0.917549 \\
\hline & $(-.242557)$ & $(16.70959)$ & \\
1982 & 645645.7 & 0.407459 & 0.591870 \\
\hline & $(1.449727)$ & $(6.103691)$ & \\
1985 & 932277.2 & 0.342793 & 0.410409 \\
\hline & $(1.600755)$ & 4.370171 & \\
1988 & 620388.1 & 0.713901 & 0.385599 \\
\hline & $(0.701271)$ & $(4.161447)$ & \\
1991 & -5677.44 & 0.514078 & 0.601022 \\
\hline & $(-.1048)$ & $(6.337707)$ & \\
\hline & 591618.6 & 0.457981 & 0.444243 \\
\hline & $(0.969181)$ & $(4.667230)$ & \\
\hline & 303616.9 & 0.615572 & 0.518659 \\
\hline
\end{tabular}

Source: Own analysis.

The increase in the use of capital over time and across the 27 subsectors thus resulted in an increase in electricity consumption by manufacturing. This conclusion has been reached from the calculation of the correlation coefficients between capital and energy within each subsector over the time period and the estimation of the simple regression of energy on capital across all the subsectors.

\section{REDUCTION OF ELECTRICITY CONSUMPTION IN THE SOUTH AFRICAN MANUFACTURING SECTOR: SOME POLICY OPTIONS}

It has been established that the low electricity prices (based on low coal prices) contribute to the high and increasing, but often inefficient, consumption of electricity. This consumption of electricity contributes significantly to the emission of greenhouse gases and other negative social and environmental externalities. Since 1970 the production structure in the manufacturing sector, the single most important consumer of electricity with the highest energy 
intensity ${ }^{3}$ of all economic sectors (Doppegieter, 1999: 67), has changed dramatically in favour of capital at the expense of labour. The increased use of capital has also contributed to the increased use of electricity as a productive input. Furthermore, the price of electricity is a weak policy instrument to manage the consumption of electricity. Diesendorf (1996) concludes also that correct pricing of electricity is not sufficient for efficient electricity consumption.

Since electricity consumption is not sensitive with respect to price, it is likely that a tax on electricity consumption would have little, if any, impact as well. The probable outcome of such a tax is that it would be viewed as an additional cost item and passed on to the final consumer, depending on the price elasticity of the final product. In such a scenario, there will be high social welfare loss. O'Connor (1999: 96) supports this view, arguing that a tax on electricity is only effective if price elasticity is high and substitutes cause less pollution. Whalley (1999: 123) is concerned that environmental tax policy may become so complex, that it would be of little use given its difficulty of implementation.

Another policy option is to prescribe maximum levels of electricity intensity per industrial subsector by legislation. This would mean a cap on electricity consumption per unit of production. Such legislation however implies high transaction costs on account of the policing and implementation of such a system, and is open to abuse. The required institutions to implement and manage such environmental legislation in developing countries tend to be weak and ineffective. This further adds to the high transaction cost of this policy option (see also Da Motta, Huber \& Ruitenbeek, 1999: 184).

In principle, a subsidy is an inefficient policy instrument since it causes social welfare losses (Rosen, 1998: 295-97). Under some circumstances, one could convincingly argue that a subsidy is a temporary measure to facilitate the change between two different policy and operational regimes. Such regimes might include a change in technology to bring about a reduction in pollution. In this regard, however, Da Motta, Huber and Ruitenbeek (1999: 186) view subsidies for abatement investments as having a limited impact, stating:

Subsidies for abatement investments have, however, been of limited impact since environmental enforcement has not been effective enough to increase firms ${ }^{t}$ demand for these expenditures. Moreover firms are using these incentives inadequately because of the lack of proper follow-up procedures, in fiscal and environmental terms to monitor their investments. 
From the above discussion it follows that conventional policy measures to bring about a change in electricity consumption behaviour of firms are likely to have a negligible effect. This is so, because these policy measures address the symptom of the problem, the electricity consumption and the ensuing emissions, and not the cause, which is an inappropriate production method and high capital intensity of the production structure.

Murthy, Panda and Parikh (1997) and Pimentel et al. (1994) are convinced that electricity conservation is possible only through a change in technology and the more efficient use of electricity, brought about by a change in the production structure (i.e. capital and labour input) and method. Which technological changes are then required to bring about the desired reduction in electricity consumption? Table 10 highlights the main procedures to reduce $\mathrm{CO}_{2}$ emissions in manufacturing. These measures are in addition to those offered by Doppegieter (1998: 4-66 - 4-74), Van der Merwe and Scholes (1999), Halnaes, Callaway and Meyer (1999) and the World Bank (1998).

\section{Table 10 Selected mechanisms for reducing $\mathrm{CO}_{2}$ emissions in manufacturing}

\begin{tabular}{|l|l|c|c|}
\hline $\begin{array}{c}\mathrm{CO}_{2} \text { reduction } \\
\text { mechanisms }\end{array}$ & \multicolumn{1}{|c|}{ Application } & $\begin{array}{c}\text { Reduction } \\
\text { potential }\end{array}$ & $\begin{array}{c}\text { Need for new } \\
\text { technology }\end{array}$ \\
\hline $\begin{array}{l}\text { Energy intensity } \\
\text { reduction }\end{array}$ & $\begin{array}{l}\text { Housekeeping (mainte- } \\
\text { nance) Conservation } \\
\text { Fundamental process } \\
\text { changes }\end{array}$ & $\begin{array}{l}\text { Low } \\
\text { High } \\
\text { High }\end{array}$ & $\begin{array}{c}\text { Medium } \\
\text { High }\end{array}$ \\
\hline $\begin{array}{ll}\text { Energy source } \\
\text { switching }\end{array}$ & $\begin{array}{l}\text { Coal/oil to natural gas } \\
\text { Fossil fuels to electricity }\end{array}$ & $\begin{array}{l}\text { High } \\
\text { High }\end{array}$ & $\begin{array}{l}\text { Low } \\
\text { High }\end{array}$ \\
& Co-generation & Medium \\
Flow changes & Fossil fuels to biomass & Medium \\
& Materials recycling & High & High \\
& Materials substitution & High & High \\
& Process integration & High & High \\
\hline
\end{tabular}

Source: International Energy Agency, 1994: 132.

From Table 10 it may be concluded that technology options for reducing electricity consumption are in fact available. One major objection to the introduction of these technologies would be the additional cost burden that it would imply. This is, however, not necessarily true. South African industry may greatly benefit from international trade using the flexible mechanisms ( $c f$. clean development mechanisms (CDM)) considered under the banner of global climate change policies within the Kyoto protocol framework (see Zhang, 2000). 
South Africa acceded to the Kyoto Protocol on 13 June 2001. Many studies have indicated that developing countries, such as South Africa, have a lot to gain from CDM projects (World Bank, 2000; OECD, 1999 \& KPMG, 2000). Pending international agreement on the CDM process and mechanisms, a way does exist of gaining superior, clean, technology without having to pay the full bill.

\section{CONCLUSION}

Electricity intensity in the South African manufacturing sector is particularly high. This in itself may not be a problem, but it contributes greatly to the generation of electricity, which in turn significantly contributes to the emission of greenhouse gases and other pollutants. These negative externalities have very high social and environmental costs. It is therefore important to reduce the electricity consumption of the manufacturing sector.

Electricity consumption in the manufacturing industry is, however, not price sensitive. To use price as a policy tool to reduce the consumption of electricity will therefore not contribute much. Therefore, to reduce consumption one of three options is available. Apply conventional policy mechanisms, use electricity more efficiently through a change in technology or substitute labour for capital.

From this study it seems that none of the conventional policy mechanisms, that is, taxes, legislation or subsidies, would achieve the objective of a cost-effective permanent reduction in electricity consumption. The substitution of labour for capital in South Africa, however laudable, is likely to be restricted by numerous socio-political factors.

The global climate change debate, in terms of the Kyoto protocol, and especially the flexible instruments such as clean development mechanisms (CDM) proposed by the protocol, has brought a unique opportunity for South African firms. South African firms can exchange their old technology for a better one, gain in foreign direct investment and contribute to a cleaner environment. This seems an effort well worth investigating.

\section{ENDNOTES}

1 The authors would like to thank all those who have contributed to this paper, but are solely responsible for all remaining errors and the views expressed here are those of the authors and do not reflect those of the 
authors and do not reflect those of any institution that they may be involved with.

2 The price elasticity of electricity demand is calculated as the percentage change in the demand for electricity divided by the percentage change in the price for electricity. This implies that the change in demand is solely due to a change in price.

3 Calculated by dividing the real GDP at factor costs by final energy use.

\section{REFERENCES}

1 ANC (1994) The Reconstruction and Development Programme. Johannesburg: Umanyano Publications.

2 CHAMBER OF MINES (2000) Mining Statistics in Brief 1999. Johannesburg: Chamber of Mines.

3 DA MOTTA, R.S., HUBER, R.M. \& RUITENBEEK, H.J. (1999) "Market Based Instruments for Environmental Policymaking in Latin America and the Caribbean: Lessons from Eleven Countries", Environment and Development Economics, 4: 177-201.

4 DEPARTMENT OF MINERALS AND ENERGY (DME) (1995) South African Energy Statistics No. 2. Pretoria: Department of Minerals and Energy.

5 DEPARTMENT OF MINERALS AND ENERGY (DME) (1999) South Africa's Mineral Industry 1998/99, Pretoria: Department of Minerals and Energy.

6 DEPARTMENT OF MINERALS AND ENERGY (DME) (2000) South African National Energy Prices, June 2000, Pretoria: Department of Minerals and Energy.

7 DIESENDORF, M. (1996) "How Can a "Competitive" Market for Electricity Be Made Compatible with the Reduction of Greenhouse Gas Emissions?" Ecological Economics, 17: 33-48.

8 DOPPEGIETER, J.J., DU TOIT, J. \& LIEBENBERG, J. (1998) Energy Futures 1998/99, Stellenbosch: Institute for Futures Research.

9 DOPPEGIETER, J.J., DU TOIT, J. \& LIEBENBERG, J. (1999) Energy Indicators 1999/2000, Stellenbosch: Institute for Futures Research.

10 ESKOM Annual Report, Various issues, Johannesburg.

11 HALNAES, K., CALLAWAY, J.M. \& MEYER, H.L. (1999) Economics of Greenhouse Gas Limitations, Riso, Denmark: UNEP.

12 HOUGHTON, J.J., MEIRO FILHO, L.G., CALLANDER, B.A., HARRIS, N., KATTENBERG, A.. \& MASKELL, K. (1996) Climate Change 1995, "The Science of Climate Change. Contribution of Working Group I to the Second Assessment Report (SAR) of the Intergovernmental 
Panel on Climate Change (IPCC), Cambridge: Cambridge University Press.

13 INTERNATIONAL ENERGY AGENCY (1994) Energy and Environmental Technologies to Respond to Global Climate Change Concerns, Paris: IEA/OECD.

14 KPMG (2000) South African National Strategy Study on CDM. Unpublished report to the National Climate Change Committee, Cape Town: KPMG.

15 MURTHY, N.S., PANDA, M. \& PARIKH, J. (1997) "Economic Growth, Energy Demand and Carbon Dioxide Emissions in India: 1990-2020, Environment and Development Economics, 2: 173-93.

16 NATIONAL ELECTRICITY REGULATOR (NER) (1998) Lighting Up South Africa: 1997/1998, Johannesburg: NER.

17 NATIONAL ELECTRICITY REGULATOR (NER) Various issues. Electricity Supply Statistics, Johannesburg: NER.

18 O'CONNOR, D. (1999) "Applying Economic Instruments in Developing Countries: from Theory to Implementation, Environment and Development Economics, 4: 91-110.

19 ORGANISATION FOR ECONOMIC CO-OPERATION AND DEVELOPMENT (OECD) (1999) Implementing Domestic Tradable Permits for Environmental Protection, Paris: OECD.

20 PIMENTEL, D., HERDENDORF, M., EISENFELD, S., OLANDER, L., CARROQUINO, M., CORSON, C., MCDADE, J., CHUNG, Y., CANNON, W., ROBERTS, J., BLUMAN, L. \& GREGG, J. (1994) "Achieving a Secure Energy Future: Environmental and Economic Issues", Ecological Economics, 9: 201-19.

21 ROSEN, H.S. (1998) Public Finance, New York: McGraw-Hill.

22 STATISTICS SOUTH AFRICA (Stats SA) (1995) Census of Electricity, Gas and Steam 1995, Pretoria: Statistics South Africa.

23 STATISTICS SOUTH AFRICA (Stats SA) Various issues, Census of Manufacturing, Pretoria: Statistics South Africa.

24 UNITED NATIONS FRAMEWORK CONVENTION ON CLIMATE CHANGE (UNFCCC) (2000) The Hague 2000: Sixth session of the conference of parties UN Framework Convention on Climate Change. Press Kit, http://cop6.unfccc.int/pdf/presskc6e2.pdf.

25 VAN DER MERWE, M.R. \& SCHOLES, R.J. (eds.) (1999) SA Greenhouse Gas Inventory, Department of Environment Affairs and Tourism: Unpublished report.

26 VAN HOREN, C. (1996) Counting the Social Costs: Electricity and Externalities in South Africa. Cape Town: Elan Press and UCT Press.

27 VAN HOREN, C. (1997) "Cheap Energy - At What Cost?" In Bethlehem, L. and Goldblatt, M. The Bottom Line, Cape Town: University of Cape Town Press. 
28 WHALLEY, J. (1999) "Environmental Considerations in Tax Policy Design", Environment and Development Economics, 4: 111-24.

29 WORLD BANK (1998) Pollution Prevention and Abatement Handbook 1998, Washington, D.C.: World Bank.

30 WORLD BANK (2000) Taxes and Tradable Permits as Instruments for Controlling Pollution: Theory and Practice, Report no. WP/00/13. Washington, D.C.: World Bank.

31 ZHANG, Z.X. (2000) "Estimating the Size of the Potential Market for the Kyoto Flexibility Mechanisms, Weltwirtschaftliches Archiv - Review of World Economics, 136(3); 491-521. 